\author{
Dovilè Jakniūnaitè \\ Institute of International Relations and Political Science, Vilnius University
}

\title{
Symbolic Foreign Policy Games: Russian - Great Britain Relations in $2006-2008$
}

\begin{abstract}
The article analyses the problems of bilateral relations between Great Britain and Russia in 2006-2008 through the conception of foreign policy symbolic games. It shows how Russia managed to create and sustain the asymmetrical relations, which allowed Russia having the initiative to define these relations and formulate the rules of the game. The article reveals how a seemingly simple story can become the long-term event of the bilateral relations, as well as demonstrates how it is possible to 'loose' the symbolic game in foreign relations first of all because of misapprehension what kind of game is played.
\end{abstract}

\section{Introduction}

By the end of the year 2007, the representatives of Russian government have gotten more and more assertive by expressing their discontent in the activities of the British Council and demanding the closure of all non-Moscow branches of this institution by 1 January $2008 .{ }^{1}$ What was the offence of this financially supported by the Great Britain agency, which the declared mission of, is to teach the youth the English language and provide the students with the study scholarships in Britain (i.e. "providing educational opportunities"2)?

The majority of the observers of the events not residing in Russia and the Britons themselves were certain that the accusations about the unclear legal status or the tax evasion meant just that behind all the demands and blames is nothing but 'political' motives. ${ }^{3}$ The description of the motive as political in

\footnotetext{
${ }^{*}$ Dr. Dovile Jakniūnaite is a lecturer of the Institute of International Relations and Political Science at Vilnius University. Address for correspondence: Vokiečiu str. 10, LT-01130 Vilnius, Lithuania, tel.: + 3705 2514130, e-mail: dovile.jakniunaite@tspmi.vu.lt.

${ }^{1}$ See, for example: Министерство иностранных дел Российской Федерации, Комментарий официального представителя МИД России М.Л.Камынина в связи с решением Британского Совета приостановить деятельность региональных отделений в России 2007, 12 декабря, http://www.mid. ru/ns-reuro.nsf/348bd0da1d5a7185432569e700419c7a/432569d80022027ec32573d400384fc8?OpenDoc ument, accessed 2008-08-04.

${ }^{2}$ British Council, About us, http://www.britishcouncil.org/new/about-us/, accessed 2008-07-12. Also the website of British Council in Russia, http://www.britishcouncil.org/ru/russia.htm, accessed 2008-07-12.

${ }^{3}$ Wingfield-Haye, R., Russia's new front in UK spat, BBC News, 2007, December 13, http://news.bbc. co.uk/2/hi/europe/7141708.stm, accessed 2008-09-12.
} 
this situation implied the attitude that Russia attacks the British institution because of a totally different reason, that it is lead by unknown/secret/ untold motives. The main reason to think so was, "The Law on the terms of the establishment and activity of the foreign cultural and information centres in the territory of the Russian Federation," adopted in 1995 and again remembered more than ten-years later to attack the British Council $^{4}$. Thus, very reasonable questions have arisen - why the attacks have intensified by the end of 2007 and not at the time the law was adopted, and what were the 'real' reasons for the displeasure by Russia with the institution?

It is also important that the problems encountered by the British Council in Russia were not just the problems of this institution. This issue in the context of the deteriorating Russian - British relations became the perfect example illustrating the growing mutual tensions that emerged in January 2006 during the 'spy' scandal and strengthened even more after the 'poisoning case' in London in the fall of 2006.

The diverse tensions ${ }^{5}$ did not cease till the middle of 2008, when the attention of both states was attracted by the more important events on the international arena (first of all the conflict in Georgia which started in the beginning of August 2008). Almost three years lasting unremitting disagreements have not evolved into the stormy conflict or the problem of international relations. However, these tensions were enough to create the mutual mistrust that all the time was on the verge of the open hostility.

This case allows formulating at least two questions about the analysis of the bilateral state relations that require deeper consideration. First, what does it mean and what is going on when the technical, routine, disagreements become the indicators of interstate relations and problems? Second, why do the states get involved in such conflicts? The assumption of the article is that through the analysis of the particular 'micro' issues and the micro strategies of the states in these problematic areas allows the better understanding of the behaviour of a state, its foreign policy and a more exact description of bilateral state relations in general.

The state interactions in this article are approached through the idea of symbolic games. Varios games, the main goal of which is to send the indirect message for the other side, are far from being the great news in international politics. Various diplomatic strategies are used for that. It is the prevalent understanding that the diplomacy can be used and often is used, in a symbolic way, implicitly seeking the strategic advantage in the foreign policy. On the other hand, not all events of everyday bilateral foreign policy usually become the problem of public diplomacy. What is chosen as a matter of public attention and how it happens, is as important as the efforts to grasp the reasons for such activities.

\footnotetext{
4 Комментарий официального представителя МИД России М.Л.Камынина.

5 Starting with various 'spy' scandals, 'name calling' and ending with the commercial disputes.
} 
Thus, the aim of the article is through the analysis of the Russian British bilateral tensions ('games') during the three years to show the role of the symbolic games in foreign policy and to demonstrate how Russia has managed to create and keep the asymmetrical relations with Great Britain, which allowed Russia to have the initiative to define the bilateral relations and formulate its own rules of the game. ${ }^{6}$ The article not only reveals how superficially insignificant news can become the story of the week, or even the month, but also shows how it is possible to 'loose' the symbolic game of foreign policy first of all because of the misapprehension on what kind of game is played.

The first part of this article explains the notion of the analysis of the foreign policy interaction through the symbolic games approach. Further the analysis of relations between Russia and Great Britain in 2006-2008 is executed with the purpose to clarify the bilateral tensions using the three-stage model, which approaches the games states play through the normative context (background knowledge), facts, and dialogue analysis. The last part of the article discusses the importance and perspectives of the symbolic games in foreign policy analysis.

\section{Games and the Everyday of the Foreign Policy}

The biggest part of a state foreign policy consists of the routine everyday activities and procedures. The documents are prepared, the bilateral and multilateral visits are organised, the positions in international organisations are formed, the formulation of the opinions are coordinated, and the meetings take place where the majority of the speeches made and documents signed do not become publicly important. Of course, the latent, not visible nature of many foreign policy events does not imply that they are irrelevant. They can influence the groundbreaking changes and other significant events, even if they themselves are incremental and for the most of us, invisible. Many perceptible things in foreign policy - the summits of the state leaders, celebratory signing of the agreements, the loud threats or critique - are the consequence of these mostly unseen everyday processes of foreign policy.

The public side of the foreign policy usually attracts more attention from the commentators and researchers. It is an easily accessible material allowing interpreting the actions of the states, their motives, identifying their interests and long-term goals. At least the assumption is very often made that such policy discloses the 'real' state interests and strategic plans. Another analytical strategy can be also chosen: one may have the system of theoretical propositions

\footnotetext{
${ }^{6}$ The time scope of the analysis is almost three years (from 2006 till the middle of 2008). The first incident which indicates the chronological beginning of the analysis happened in yearly 2006 and, as it became clear later, was just one among many signs of the worsening bilateral relations. The data for the analysis consist of the public statements by both states regarding the analysed issues and the bilateral relations in general. The effort was made to collect the majority of the statements.
} 
on why the states behave one way or another and relying on them he or she may interpret the particular everyday or occasional events. In both cases the epistemological ground is that it is possible to know and identify the states' interests, that these interests are more or less stable, defined, and naturally stem from the certain characteristics of a state.

Such thinking is based on the idea that state foreign policy is instrumental in defending the national interests and at the same time expressing these interests or signalling about their changes. This perspective looks at the agency of the states as strategic, mainly consistent, systemic behaviour. In the context of this article such a view can be called a 'macro' view because first of all it defines the general principles of the state behaviour, and after that, uses them to explain the particular events. ${ }^{7}$

Such an approach by itself is not faulty. The statements about the state actions that are taken as given, have anyway been formulated analysing state practices. However, this way of thinking is problematic because of two reasons. Firstly, the general patterns of state actions are frequently accepted as laws, and secondly, these patterns are formulated so that the general theories of the state agency do not provide with any tools to analyse the particular interactions of the states (or in other words, do not indicate how to perform the empirical research).

It is also possible to look differently at the public disagreements of the states and, in general, at the foreign policy events - to consider them as social practices through which the states not only declare (implicitly) their goals, but at the wider extent are formulating the definitions of themselves and their relations, constructing them in the public 'micro' battles. At the same time during these public confrontations the rules of these interactions are also frequently constructed.

Social practices are important in any social interaction, because they are the regularities and activities that connect the social structure with the actions of the actors. Social practices are also the indicators allowing the distinguishing of structural constraints and the subjectivity of the actor. ${ }^{8}$ The concepts and their meanings (through the naming) are created through practices as well. According to McSweeney, we rely on their usual capability to reproduce their meaning in certain situation or action in order to confirm or modify it. ${ }^{9}$

Thus, no initial premise is made on what the state, behaving one way or another, seeks. Instead, the action itself has to disclose the meaning of the agency and interactions. This perspective asks how the states themselves inte-

\footnotetext{
${ }^{7}$ Of course, the traditional term 'realism' also can be applied here. In this case, the most relevant is its emphasis on the states as predictable, familiar, and relatively stable entities of the international relations and on their goals and interests determined by their capabilities, frequently understood as power. The biggest methodological flaw of this attitude is the self-fulfilling hypotheses.

${ }^{8}$ For more elaborate version of this argument see: Jakniūnaite, D., Kur prasideda ir baigiasi Rusija: kaimynystè tarptautinejje politikoje, Vilnius: Vilniaus universiteto leidykla, 2008, Ch.1.

${ }^{9}$ McSweeney, B., Security, Identity and Interests: A Sociology of International Relations. Cambridge: Cambridge University Press, 1999, P. 161.
} 
racting with each other formulate their interests, goals and objectives, and at the same time create and/or modify the rules of the game, the mutual definitions and the main concepts of their interactions. Mostly the bilateral interactions shape the mutual interpretations. That is why at the centre of the analysis is the practice analysis.

Practice analysis allows also defining the relation between visible and invisible foreign policy processes. According to this approach, the public space of the game builds the ground and the context that make the majority of the everyday, invisible activities possible.

Action is impossible without the ideas. Laffey and Weldes call them "symbolic technologies", emphasising that they are "intersubjective systems of representations and representation-producing practices"10. That is the ideas are social, they are not the individual level phenomena, they are collective and shared. Ideas come into existence because of the collective social actions. They are the systems of representation formed in the specific spatial, temporal, and cultural relational environment where more or less clearly articulated systems of meaning are circulating.

What options this approach on the role of the ideas (meanings) in the social practices provides for the analysis of the bilateral interactions among the states? It gives the understanding about the importance of the meanings in the social interaction. Here the understanding of foreign policy proposed by Barnett is very useful. He asserts that to understand foreign policy is to understand "the normative structure that constitutes and constrains actors also provides the wellspring for social practices and allows for strategic action", and "such strategizing occurs in a normative and an institutional context" ${ }^{\prime 11}$, meaning that any action has its own normative and institutional constraints. It describes the boundaries of the agency, and does that through the established values and procedures. The structural constraints, however, do not allow ignoring the fact that actors play strategic games. Thus, the everyday state interactive practice can be defined as a game. This term emphasises the mutuality of the notions from one side the existence of certain rules of practice, on the other side, their formation during the process of the game - and, finally it pays the attention to the consciousness of the actors in that process, that is to their strategic and purposeful behaviour.

The strategic games, however, rarely are direct and obvious games about the clear goals. The games in foreign policy often are symbolic, i.e. the object of the particular game is not the most important goal, and the game appears to be played because of the different motives. Relatively 'insignificant' problems of foreign relations (in the sense of their everydayness and commonness) when they become the issues defining the bilateral relations are especially useful for

\footnotetext{
${ }^{10}$ Laffey, M., Weldes, J., Beyond Belief: Ideas and Symbolic Technologies in the Study of International Relations, European Journal of International Relations 3 (2), 1997, P. 208.

${ }^{11}$ Barnett, M., Culture, Strategy and Foreign Policy Change: Israel's Road to Oslo, European Journal of International Relations, 5 (1), 1999, P.5.
} 
the analysis of the symbolic games. So, the bilateral interactions between Russia and Great Britain are defined as symbolic games because these interactions initially being the part of the everyday foreign policy during the interaction have become symbolically important for both sides, and in this way marked the start of the different game. The analytical part of the article tries to understand what kind of play has been started and how.

Analysing symbolic games the model of language games analysis proposed by Duffy, Frederking, and Tucker ${ }^{12}$ is used. The analytical instrument for the language games can be used for the symbolic games as well. The games become games first of all and mainly through the language in certain time and place. ${ }^{13}$ According to the authors mentioned, any language game must be analysed through the three steps: first, the values and attitudes of the actors, second, the facts of the game, and, third, the dialogue itself. The values and attitudes of the actors in this case are the states conceptualisations on what is important in international politics, what their place is and how they should act in this environment. This explanation about the place of the country in the world reveals the structural constraints of the state behaviour (as understood by the state itself). Inventory of the facts is far from straightforward activity, it helps to identify what is held as important in any event and how it is done. Dialogue analysis encompasses the analysis of the situation which has arisen from the interaction and the evaluation of the dynamics of the bilateral games in the context of their foreign policy.

\section{Normative Context of the Russian - British Relations}

The first step analysing symbolic games is to comprehend the system of the main normative and value positions of two players. The system first of all encompasses the conceptualisations of the international politics by the states and the description of their place there. Such conceptualisations and descriptions show the (perceived) structural constraints of each state. In the foreign policy analysis the normative context is best represented in the foreign policy conceptions or programs (not necessary officially called as such). For the goals of the article it is important to understand the essential differences (and similarities as well) between the world-views of Russia and Great Britain. It will indicate the limits that could and would not be overstepped even by the most pragmatic foreign policy strategy.

Recently the leadership changed in both countries: in 2007 in Great Bri-

\footnotetext{
${ }^{12}$ Duffy, G., Frederking, B.K., Tucker, S.A., Language Games: Dialogical Analysis of INF Negotiations. International Studies Quarterly 42, 1998, p. 271-294.

${ }^{13}$ More about the importance of the language in international relations analysis see: Fierke, K. M., "Links Across the Abyss: Language and Logic in International Relations", International Studies Quarterly 46, 2002, P. 351.
} 
tain and in 2008 in Russia. The change of the political leaders combined with the changing international environment was a good opportunity to review the foreign policy principles or to give more precise wording. Neither of two states made any radical turns, it was more a 'codification' of the established foreign policy practices.

At the end of the summer of 2008, the President of Russian Federation Dmitriy Medvedev summarized the principles of Russian foreign policy: Russia accepts the primacy of the international law and thinks the multi-polarity should prevail in the world. Russia does not want any confrontation with any state, its main priority is to defend the citizens of Russia all around the world, and finally he acknowledged that "Russia, like other states in the world, has regions where it has the privileged interests" ${ }^{\prime 14}$. In the New Foreign Policy Conception, besides these issues, the accent on the importance of the national sovereignty was put and the attention to the Commonwealth of Independent States was indicated. ${ }^{15}$

Russia understands and tries to stress its subjectivity in international politics by emphasising its territoriality and the geopolitical worldview that is expressed through the identification of the clearly defined geographical sphere of influence. However, the respect for the principle of sovereignty has one, but important exception - it can be overshadowed by the necessity to protect the citizens anywhere and at any time. It was possible to observe the peculiar implementation of this principle during the Georgian events that started in August 2008 when Russia acknowledged the independence of two Georgian territories. Thus the declared respect for the international relations principles, especially for the institution of the United Nations notwithstanding, Russia persistently attempts to influence the formulation and modification of the international rules and demonstrates the desire and demand for the respect as the influential player of the international system.

The new Secretary of State for Foreign and Commonwealth Affairs of the United Kingdom, David Miliband, outlined the foreign policy priorities and conception in the summer of 2007. He declared that Britain should respond to challenges, "by using our strengths so that we are a force for good for Britain by being a force for good in the world"16. The power of the country was described as the combination of hard and soft power, which is devoted towards the strengthening of international security and prosperity, not avoiding international involvement and solving security problems. This position on international involvement is defined as 'liberal interventionism ${ }^{\prime 17}$, because

\footnotetext{
${ }^{14}$ Интервью Дмитрия Медведева телеканалам «Россия», Первому, НТВ, 2008, 31 августа, http://www. kremlin.ru/appears/2008/08/31/1917_type63374type63379_205991.shtml, accessed 2008-10-13.

${ }^{15}$ Концепция внешней политики Российской Федерации.

${ }^{16}$ Miliband, D., New Diplomacy: Challenges for Foreign Policy, Speech at the Chatham House Royal Institute of International Affairs, 2007, July 19, http://www.chathamhouse.org.uk/files/10188_190707miliband. pdf, accessed 2008-09-12, P.2.

${ }^{17}$ Lawson, D., David Miliband, Prospect Magazine, 2008, October, Issue 151, http://www.prospect-magazine. co.uk/article_details.php?id=10395, accessed 2008-12-01.
} 
"if we are to continue to be a force for good, we need to be smart about how and when we combine the soft power of ideas and influence and the hard power of economic and military incentives and interventions"18. The agency of Britain in international politics, according to its Foreign Affairs secretary, is primarily based on the winning the battle for ideas, after the influence in the international institutions follows ("[m]ultilateral action is not a soft option"), only then incentives and sanctions may be used, keeping in mind that "there will be cases where direct intervention will be right ${ }^{\prime \prime 19}$. It is acknowledged that the shared values are not enough; they have to be embodied in the shared institutions. ${ }^{20}$

So, despite Russia's attention to its 'own' regions, the emphasis on the national sovereignty principle and British efforts to become 'force for good' and 'responsible sovereignty ${ }^{\prime 21}$, the difference in the normative positions of these two states cannot be straightforwardly described as the difference between the realist and liberal world-view. At least two factors create the overlapping space for understanding and shared interpretations: on one hand, both states recognize the importance of international institutions (in the Russian case, especially with regards to the UN), on the other hand, there is a common understanding how important the 'hard' power still is. Both states see the interconnected world with the problems that are mostly transnational and cannot be solved by the efforts of the single actor.

Grasping with the differences between the normative positions superficially, the distinction between the protection and preference, for interest (Russia) and values (Great Britain) seems valid. The differing language about the international politics would suggest such a conclusion. However, this distinction in foreign policy conceptions can hardly be considered as important. First, there is no theoretical opposition between the values and interests of the state. The understanding of the national interests does not come by itself; the interests are based on the value statements about the self, the goals and the surrounding world. ${ }^{22}$ Second, such a distinction creates the asymmetrical opposition between two positions where the value position is treated as moral and the interest politics frequently - as immoral, thus, consequently the states are divided into good and bad ones. Any analysis has the goal to avoid that.

Still, speaking about the politics of one's state the particularities in the proposed argumentation allow the distinguishing of an important difference in foreign policy conceptualisations. When Great Britain's politicians speak about the place of their country in the international politics they emphasise the outside (e.g. how it will contribute to the solutions of the world problems). Meanwhile, Russia's language is much more defensive and suspicious, Russia starts from itself, from inside, and the outside relations just validate or should

\footnotetext{
${ }^{18}$ Miliband, New Diplomacy: Challenges for Foreign Policy, P. 3.

${ }^{19}$ Ibidem, P. 5-6.

${ }^{20}$ Miliband, D., Speech to the 2007 Labour Party conference, 2007, September 25, http://news.bbc.co.uk/1/ hi/uk politics/7012356.stm, accessed 2008-11-07.

${ }^{21}$ Lawson.

${ }^{22}$ More see: Finnemore, M. National Interests in International Society. Ithaca: Cornell University Press, 1996.
} 
validate the internal conceptions of the state (whereas Great Britain gets more of internal definitions from the results 'out there'). To what extent these normative similarities and differences influence the differences in the everyday foreign policy behaviour, and even more importantly, how they do that is shown in the next sections.

\section{Chain of Bilateral Disagreements}

The second step analysing the games according to Duffy, Frederking and Tucker ${ }^{23}$ is making of an inventory of the facts. This does not mean the finding out what truly happened. The goal is to highlight what became significant in the Russian British relations during the analysed period, what events have been treated as meaningful and worth to be used as defining these same relationships. In other words, the symbolic game not only includes the way how it is played but also how it is chosen which game to play.

It is impossible not to notice the fact that during the last several years many states would negatively describe their relations with Russia. The list of the disagreements is rather extensive - the yearly disputes about gas supply, US missile shield in Europe, deferring views on Iran nuclear programme and fight with the terrorism, commercial disputes and boycotts, border disagreements, discussions about Russian speaking population, etc. Many of these problems, even if they may be solved bilaterally, are shared and are applicable to the majority of European states. Even in such a strained context, the Russian British relationships appear to be special, and both states admit that their communication is 'especially not normal'.

The new Russian Foreign Policy Concept of Russian Federation of 2008 is very telling. Here is the paragraph devoted to the Russian relations with European countries:

The development of mutually advantageous bilateral relationships with Germany, France, Italy, Spain, Finland, Greece, the Netherlands, Norway and some other West European states is an important resource for promoting Russia's national interests in European and world affairs... Russia would like the potential for interaction with Great Britain to be used along the same lines. ${ }^{24}$

The Survey of Russian Foreign Policy one year earlier stated even more directly: "Great Britain stays an important, though difficult partner"25. Thus, Russia 'codified' very quickly the disagreement with one European country as worth singling out.

\footnotetext{
${ }^{23}$ See Duffy, G., Frederking, B.K., Tucker, S.A., Language Games.

${ }^{24}$ Концепция внешней политики Российской Федерации.

${ }^{25}$ Обзор Внешней Политики Российской Федерации, 2007, http://www.ln.mid.ru/ns-osndoc.nsf/0e9272b efa34209743256c630042d1aa/d925d1dd235d3ec7c32573060039aea4?OpenDocument, in English - http:// www.mid.ru/ns-osndoc.nsf/0e9272befa34209743256c630042d1aa/cef95560654d4ca5c32574960036cdd b?OpenDocument, accessed 2008-09-12.
} 
The same caution can be seen in the British position as well. One of the most recent examples happened in July 2008, before the meeting of new Prime Minister of UK Gordon Brown with the freshly elected President of Russian Federation Dmitriy Medvedev at the G8 meeting. Just before this meeting the report was disseminated, which stated that British security services have identified Russia as the third most serious threat to UK, placing it after al-Qaeda terrorism and Iranian nuclear proliferation. ${ }^{26}$ The Foreign Affairs Committee of the House of Commons in its turn already in 2007 asserted that the "state-to-state relationship between the UK and Russia has deteriorated markedly in recent years" and "there has been a string of irritations" ${ }^{\prime 27}$. British propositions have been more cautious when declaring rough relations (unofficially through the reports or softer wording), still however, no other state with which the routine foreign policy activities are maintained has not been singled out in such a way.

What 'micro' events have created the basis to describe the British - Russian relationships as bad and deteriorating? What strategic actions ('moves') have been made and how has each party been constructing this relationship game? The bilateral tension started during the first months of 2006 when Russian secret service accused the British diplomats of spying. This was done publicly, through the press. As proof the artificial stones with the electronic spying devices found in one of the Moscow parks were presented. Soon after that, Federal Security Service (FSB) publicly accused the embassy of United Kingdom of using the nongovernmental organizations for spying. ${ }^{28}$ As one British diplomat evaluating the situation contended, the systemic "pattern of unofficial and deniable acts of hostility towards UK interests" ${ }^{\prime 29}$ has started. British officials refused to comment on the accusations, Russia did not proceed further and the incident disappeared from the public discussions.

The explosion in bilateral relations happened in November 2006, when the 'Litvinenko case', as it was named later, began. ${ }^{30}$ Aleksandr Litvinenko, the former agent of Russian security services, died from the radioactive poisoning and just before his death he accused Vladimir Putin, the President of Russian Federation at that time, of a conspiracy against him. After Scotland Yard's investigation the main suspect that emerged was the former KGB agent Andrey Lugovoy. The story became even more complicated after the request by British policy to extradite Lugovoy and Russia's refusal to do that. The principal

\footnotetext{
${ }^{26}$ Webster, P., Russia rated UK's biggest threat after al-Qaeda and Iran, TimesOnline, 2008, July 4, http:// www.timesonline.co.uk/tol/news/uk/crime/article4265569.ece, accessed 2008-10-01.

${ }^{27}$ Global Security: Russia, House of Commons Foreign Affairs Committee, Second Report of Session 2007-2008, London: The Stationary Office Limited, 2007, http://www.fco.gov.uk/resources/en/pdf/RussiaGlobal-Security, accessed 2008-09-14, P. 43.

${ }^{28}$ UK diplomats in Moscow spying row, BBC News, 2006, January 23, http://news.bbc.co.uk/2/hi/europe/4638136.stm, accessed 2008-08-02.

${ }^{29}$ Global Security: Russia, P. 43

${ }^{30}$ The chronology of the events can be found here: http://www.litvinenko.org.uk/news/en/chronology/; or here: Timeline: Litvinenko death case, BBC News, 2007, July 27, http://news.bbc.co.uk/2/hi/uk_news/6179074. stm, accessed 2008-07-20.
} 
argument against that was the provision of the Russian constitution, which prohibits the extradition of Russian citizens if there is a possibility they might be brought to the court. The Russian side also asserted that British officials not providing proof are behaving inappropriately and forget that Russia has many times requested in wane to extradite Russian citizen resigning in Great Britain. ${ }^{31}$ Great Britain tried to appeal to the principles of justice and not to move away from juridical discussions (the mentioning of the Russian exiles in Britain, especially keeping in mind the notorious Boris Berezovskiy, did exactly the opposite: it politicized the questions even with juridical terminology).

The majority of the incidents have begun by being initiated by Russia, or only indirectly by Great Britain. However, in July 2007 Great Britain made its first open diplomatic demarche against Russia. Britain, still very dissatisfied with the uncooperative behaviour of Russia investigating Litvinenko's death and the extradition refusal, has expelled four Russian diplomats from the country.

Russia taking little time to think took "analogous and balanced" 32 countermeasures and sent four British diplomats from Russia (besides, officially froze the cooperation between security services, negotiation on cultural centres, and with this move created favourable condition for the subsequent British Council 'scandal' ${ }^{\prime 3}$ ) and commented their actions in this way:

Moscow's measures ... are balanced and necessary. The Russian side was forced to make them taking into account the conscious choice by London to aggravate the relations with Russia ... In such cases the principle of reciprocity has to work ... [The British position] is based on anything except the common sense usually typical for British pragmatism and the rule of law. The demand to change the Constitution in order to get one suspect in the 'Litvinenko case' is the perfect example ... We hope that finally the common sense will prevail and Russian - British relations will not be hindered by artificial obstacles - may it be domestic political junctures, or the use of "Russian card" in European and Euroatlantic political context. ${ }^{34}$

In the parliamentary report by the House of Commons these events were commented as "the most serious deterioration in bilateral diplomatic relations since the end of the Cold War"35.

The British Council 'scandal' that began in the end of 2007 attracted similar public flames and media attention. This institution has been active in Russia since 1992 and at some point had the diplomatic status. In 2004, the Ministry of Foreign Affairs of the Russian Federation made a statement that

\footnotetext{
${ }^{31} \mathrm{See}$, for example, Стенограмма ответа на вопрос СМИ Министра иностранных дел России С.В.Лаврова на пресс-конференции в Лиссабоне 19 июля 2007 года, http://www.mid.ru/ns-reuro.nsf/348bd0da1d5a $7185432569 \mathrm{e} 700419 \mathrm{c} 7 \mathrm{a} / 432569 \mathrm{~d} 80022027 \mathrm{ec} 325731 \mathrm{e} 001 \mathrm{fe} 7 \mathrm{ff}$ ?OpenDocument, accessed 2008-10-02.

${ }^{32}$ Ibidem.

${ }^{33}$ Ibidem.

${ }^{34}$ Министерство иностранных дел Российской Федерации, Комментарий МИД России по российскобританским отношениям, 2007, 19 июля, http://www.mid.ru/ns-reuro.nsf/348bd0da1d5a7185432569e 700419c7a/432569d80022027ec325731d004ad280?OpenDocument, accessed 2008-09-04.

${ }^{35}$ Global Security: Russia, P. 11.
} 
it does not consider the offices of the council part of the diplomatic mission. Then the attack was overtaken by the Ministry of Interior Affairs that accused the institution of the illegal activity (illegal teaching) and tax evasion. The reaction of the British council was quick, the problem seemed to be solved and the case was dismissed. ${ }^{36}$

However, in October of 2007 Russia demanded to stop the activity of all non Moscow offices from January 1, 2008, indicating the Law on the terms of the establishment and activity of the foreign cultural and information centres in the territory of Russian Federation adopted in 1995. The political accusations have been also uttered. For example, in Krasnoyarsk the local powers accused the Council of 'brain drain' because the institution was seducing Russian students with the scholarships in UK universities. ${ }^{37}$ At the meantime, Great Britain has been trying to prove that the Council is part of the embassy and has to have the diplomatic immunity ${ }^{38}$ or has been emphasising the political nature of the demands. ${ }^{39}$ From the other side, the Minister of Foreign Affairs of Russian Federation Sergey Lavrov in a statement on 14 December 2007 confirmed that the attack is connected with the 'Litvinenko case', so, in a way proving the assumptions by British. However, later the statements of such kind have not emerged again.

January 2008 the ambassador of the UK was informed that Russia would take "strict measures" if the British Council offices in St. Petersburg and Yekaterinburg would not stop working and the eventual British resistance was called "the planned provocations to worsen the relations between Russia and Great Britain" 40 . Next day FSB called several employees of the Council for questioning, and after a couple of days - on January 17 - the offices of the British Council were closed.

During these several months of confrontation the officials from both sides made a lot of strong and harsh assertions. The ambassador of Great Britain Anthony Brenton said that "Russia is the only one who lost in this case" ${ }^{\text {"41 }}$ and that night when the British Council employees had been questioned they were making references to the Cold War and the Soviet methods in order to deal

\footnotetext{
${ }^{36}$ МИД РФ проводит антисоветскую политику, Коммерсанть, 2007, 14 июня, http://www.kommersant. $\mathrm{ru} /$ doc.aspx?DocsID=773984, accessed 2008-09-25.

${ }^{37}$ Buckley, N., Moscow steps up pressure in Moscow, Financial Times, 2007, 14 June, http://www.ft.com/ $\mathrm{cms} / \mathrm{s} / 0 / 5 \mathrm{f} 94 \mathrm{~d} 026-1 \mathrm{a} 86-11 \mathrm{dc}-8 \mathrm{bf0}-000 \mathrm{~b} 5 \mathrm{df1} 10621 . \mathrm{html}$ ?nclick_check=1, accessed 2008-10-12.

${ }^{38}$ Franklin, K., Russia to restrict British Council, Telegraph,2007, 13 December, http://www.telegraph.co.uk/ news/uknews/1572370/Russia-to-restrict-British-Council.html, accessed 2008-10-02.

${ }^{39}$ Wingfield - Haye.

${ }^{40}$ Министерство иностранных дел Российской Федерации, О вызове в МИД России посла Великобритании, 2008, 14 января, http://www.mid.ru/ns-reuro.nsf/348bd0da1d5a7185432569e7004 $19 \mathrm{c} 7 \mathrm{a} / 432569 \mathrm{~d} 80022027 \mathrm{ec} 32573 \mathrm{~d} 00042 \mathrm{fa} 0 \mathrm{e}$ ?OpenDocument, accessed 2008-09-16; Response of the Secretary of State for Foreign and Commonwealth Affairs to Second Report from Foreign Affairs Committee Global Security: Russia, 2008, February, http://www.fco.gov.uk/resources/en/pdf/FAC-Response, accessed 2008-09-16.

${ }^{41}$ Посол Великобритании о Британском совете: "Единственной пострадавшей в этой истории оказалась Россия", Коммерсантъ, 2008, 1 января, http://www.kommersant.ru/doc.aspx?DocsID=843045, accessed 2008-09-12.
} 
with the problems. Miliband was accusing Russia of a direct threat and called the story the stain in Russian foreign policy. He emphasized that the UK will take the position of "moral high ground"42, by adding: „I have decided not to take similar action against Russia's cultural activities in the UK"43.

Meanwhile Lavrov, while commenting the activities of British Council in Russia, contended that it is the "reflection of nostalgia for colonial times" and stated that "this is not the language to talk with Russia"44. And again there were the accusations of indoctrination of Russians and seduction efforts to make them leave the country. ${ }^{45}$

Thus, in the middle of 2008 both parties had nothing left to do, but to conclude that relationships are absolutely bad and the perspectives for improvement in the nearest future are grim. According to the Ministry of Foreign Affairs of the Russian Federation:

Currently [May 2008] the Russian-British relations are far from being good. On 16 July 2007 the British government, on the ground that Moscow allegedly refuses to cooperate in the so called 'Litvinenko case', announced that it is starting to take unfriendly measures against Russia.... Just after officially expelling four Russian diplomats, London informed that it is limiting the cooperation in the fields of visas, military technical cooperation, and is freezing the relations with the FSB, which is threatening the bilateral antiterrorist cooperation that has been developing during the last years. ${ }^{46}$

In the Survey of Foreign Policy in 2007 it is also stated that "all the scope of our cooperation notwithstanding the bilateral relations and activities on the international scale, are restrained by the messianistic attitudes of the majority of the British political elite, including the attitudes regarding the internal political processes in Russia" ${ }^{47}$.

\section{The British Foreign and Commonwealth Office was equally sceptic:}

We recognise that there is a divergence in Russian and UK positions on certain issues, including the UK's greater willingness to countenance external engagement with states' internal affairs, particularly as these pertain to human rights, democracy and the rule of law. The UK strongly believes that external engagement can be an important element in ensuring international peace and security. We will continue to advocate this to Russia... Where we do have policy disagreements, we will continue to explain why we take such positions. We need to be clear, however, that Russian behaviour is sometimes not in line with the international commitments to democracy, human rights and the rule of law to which Russia has voluntarily subscribed..$^{48}$

\footnotetext{
${ }^{42}$ In full: Miliband Russia statement, $B B C$ News, 2008, January 18, http://news.bbc.co.uk/2/hi/uk_news/ politics/7194258.stm, accessed 2008-09-21.

${ }^{43}$ Ibidem.

${ }^{44}$ Russia, Britain in slanging match over cultural centres, AFP, 2008, January 15, http://afp.google.com/ article/ALeqM5jH4TWhgv1gQmM6utJgvlvurivZGA, accessed 2008-09-16.

${ }^{45}$ E.g. Buckley.

${ }^{46}$ Министерство иностранных дел Российской Федерации, Российско-британские отнотения (справочная информация), 2008, 15 мая, http://www.mid.ru/ns-reuro.nsf/348bd0da1d5a7185432569e700419 c7a/4fac8df9d8f7ddaf43256d4f00202087?OpenDocument, accessed 2008-09-04.

47 Обзор внешней политики Российской Федерации.

${ }^{48}$ Response of the Secretary of State for Foreign and Commonwealth Affairs to Second Report from Foreign Affairs Committee Global Security: Russia, 2008, February, http://www.fco.gov.uk/resources/en/pdf/FACResponse, P.3-4, accessed 2008-09-18.
} 
Of course it is difficult to say if the year 2008 has been the last of such foreign policy games. However, this quite short period of bilateral relations provides enough material to analyse the bilateral interactions between Russia and Great Britain and understand what kind of symbolic game has been played by both states.

\section{Political Games as the Expression of Symbolic Power}

The analysed events demonstrate that the foreign policy interactions are connected not only as the chain of events, but also through their discursive meanings. They appear to connect at first sight as 'illogical', unconnected phenomena and events. During the last several years, thanks to these discursive meanings, two states managed to move from reasonable bilateral relations towards the relations by both sides described as difficult. Thus, the last step of the analysis is to reveal what kind of the game was going on and the way the problems were talked about. What game was played by both sides? What 'message' each side wanted to send to another?

The first feature of the game played by the two states is its asymmetrical nature. The almost three-year story showed that it is Russia who was the one who played with Great Britain. The later, as a matter of fact, tried several times to take the initiative over, or at least to level the balance, however, did not manage to play games with Russia. That is why the reactive politics of Great Britain were defensive, angrier, and appealing to the morals and values.

Russia, in turn, formulated the firm position and did not allow any thinking about the possibility that others might mix with its matters. This asymmetric condition was of course strengthened by the fact that the stage of the political spectacle was in the most cases also in Russia and any change in scenery did help to gain the lead in playing the game. Metaphorically, such a situation can be described as the 'cat and mouse' game where Great Britain succeeded in neither swapping the roles nor changing the plot of game (for example, starting to play the not so traditional cat and mouse game, like 'Tom and Jerry').

Second, it is important to emphasize that the game played was symbolic and the hypothesis made at the beginning of the article was justified. The particular bilateral problem was not important by itself because almost always the prevailing attitude was that either the opponent that was doing something actually had in mind something else, or the player itself was playing for different reasons and having some other thoughts (sometimes even direct comments alluded to that - like such descriptions of the behaviour: 'coloni$\mathrm{al}^{\prime}$, 'undemocratic', 'wrong' etc. that have nothing to do with the situation at hand). It is not even important if the opinions of both sides, on what the real problem was, coincided or not. It was enough that it was imagined that they 
did. This logic of reasoning is apparent in 'spy scandals' or in the case of the British Council.

The 'Litvinenko case' however, was initially, a different interaction. At the beginning of the story, the events have evolved on the territory of Great Britain, therefore for the British side the event was not a foreign policy interaction at all. It was more the matter of human safety and societal security, thus the problem was more corporeal and more tangible. For Russia, the case increased in importance after its main actor, Litvinenko, accused Russia's President of conspiracy against him. At this moment it became not only the story about the disobedient and unreliable citizen, but a matter of the respect for the state and its leader, and later for its citizens (in Lugovoy's case) as well. Later comments by Great Britain trying to disentangle the case and attempts to stay in the limits of the legal discourse also demonstrate how the poisoning case, also for Britain itself, gradually became the question about the respect for the country and its values.

The 'Litvinenko case', mostly because the event became the story about the mutual respect, friendliness, and trust (more exactly, about the absence of these elements in the bilateral relations), stays the focal symbolic game. It is the main disagreement references to which are constantly made in any efforts to solve the relations.

Here, also the third characteristics of the Russian - British symbolic game unfolds - the symbolic game has the defining power.

Thus, foreign policy through such symbolic games, reveals itself as an identity formation process ${ }^{49}$. In the case of Great Britain and Russia, particularly important is the part of the process, which deals with the creation of the definitions of the Other. For example, using the term 'colonialism' Russia attempted the radical redefinition of the opponent. To accuse Britain that it cannot forget its colonial past and it still tries to implement imperial politics means to choose the same discursive strategy which is used by the British for the descriptions of Russia. This choice is the perfect way to neutralize the term 'neoimperialism', which is more and more often used to describe the Russian foreign policy. Indication that the opponent behaves in the same manner is the attempt to create the balance and basically to leave the only trump card for Britain - "the democracy and human rights discourse" which Great Britain often uses dealing with Russia. ${ }^{50}$ However, in the cases analysed here, this strategy appeared difficult to apply because of the content of the games - Russia managed to resist their normative conceptualisation according to Britain's wishes and tried to stay in the framework of neutral, objective and legalistic language.

Thus, Russia took the initiative to mould and formulate the bilateral relations not only designating the issue questions but also indicating the tone of the talk, its cycle and limits. Even by creating the equivalence in mutual

\footnotetext{
${ }^{49}$ See, for example: Campbell, D., Writing Security: United States Foreign Policy and the Politics of Identity. Minneapolis: University of Minnesota Press, 1992.

${ }^{50}$ See, for example: Global Security: Russia.
} 
descriptions (e.g. colonial-imperial opposition) Russia, in fact, got the advantage because this way it managed to destroy the asymmetrical, unfavourable and threatening to become the dominant, description of its behaviour in the international politics. ${ }^{51}$

Finally, another important feature of the symbolic game analysed in this article is that, again, Russia was the one who used the legal rhetoric to its advantage. Legal terms helped to resist normative language because it was easier to accuse the opponent of emotionalism (for example: "British efforts to politicize the topic, distort facts and use unprofitable rhetoric do not help to improve the bilateral relations ${ }^{\prime 25}$ ). The usage of legalistic language stresses the rationality, 'common sense', and objectivity. The fact that these qualities usually are attributed to the British and in the analysed cases Russia was the one claiming them for itself makes the situation even more intriguing, because we see the similar strategy again: to deny, neutralize the 'traditional' virtues of the opponent by applying them to itself.

It is worth noticing that this positional imbalance can also be explained by looking at the normative context of both states analysed in the second section. The strategic foreign policy behaviour of Great Britain based principally on the need for the external validation and successful results in the outside was not realised during the symbolic games with Russia. Meanwhile, the self-conceptualisations of Russia do not require the initial confirmation from anybody - the function of its foreign policy strategy is to manifest its identity to others. Its symbolic goal, which the development of relations with Great Britain demonstrates, is to make that the Others would also accept its self-interpretation, i.e. the idea that Russia is strong, firm, rational state, that it knows this and therefore will seek the respect and will not let itself be 'pushed' around.

Thus, the 2006 - 2008 events between Russia and Great Britain have been not only the direct conflicts about several different questions, they have also been the games, because it was understood that the struggle is not about the direct win on the particular question, but about different and much important issues. Thus, the words uttered during the disputes more important were meaning than the disputes themselves. The words did not only describe the positions on the issue, they also have been the tools to consolidate the relative position in the common discursive field of bilateral relations. That is the words and reciprocal actions had the symbolic function. Thus, it means that the fluctuation in the bilateral relations can be understood analysing the descriptions of the problems and situations and the arguments that are offered by both sides.

\footnotetext{
${ }^{51}$ It is necessary to notice that the strategy to seek balance in mutual categorisations was relatively successful in the context of this analysis; however, it should not be taken as a proof that this strategy is working or has worked in the broader context of Russian foreign policy activities.

${ }^{52}$ Комментарий официального представителя МИД России М.Л.Камынина.
} 


\section{Concluding Remarks}

The position that diplomats easily deny or renounce their words, and this does not necessarily create the consequences, is the dominant and popular view about the role of the words in the diplomatic language. In this article it was demonstrated how the uttered words become and stay as the actors in the political game. They become the participants in this game not only because they are remembered, but firstly because by their constant repetition, quotation and rehashing they start 'living their own life'. They can disappear for some time from the discursive context, but they can be easily 'reanimated' as well and made into the actors again. This, for example, happens with the Litvinenko's accusations and alleged or real Lavrov's swearing while talking to Miliband.

The processes of meaning creation analysed in the article of course are not the only ones that form and define the relations between the states. Many factors - the everyday interactions, the exceptional, celebratory events, the context of international politics, domestic processes - influence the foreign policy and help to understand it. The analysis of the symbolic games in foreign policy demonstrates how the states are acting strategically and creatively inside the limits of international politics through the naming, definitions of the self and others, and the language strategies leading or loosing the lead in the bilateral relations and solving the problems.

It is difficult to sustain such a tension for a long time without going somewhere further. So, it is likely that the relations between Russia and Great Britain will come back to being 'normal' and becoming similar to the relations between other European states. This conclusion is not supposed to mean that the symbolic fights are going to disappear from the relations between these two states, as they are not disappearing from many bilateral interactions. They usually just manifest over a longer time and through more indirect actions. 